Article

\title{
The Sound of the Unsayable: Jewish Secular Culture in Arnold Schönberg and Aharon Appelfeld
}

\author{
Michal Ben-Horin $(\mathbb{D}$ \\ Department of Comparative Literature, Bar-Ilan University, Ramat-Gan 5290002, Israel; \\ michal.ben-horin@biu.ac.il
}

Received: 9 April 2019; Accepted: 15 May 2019; Published: 19 May 2019

\begin{abstract}
This article examines the use of central elements of the Jewish religious repertoire and transcendental realm, such as prophecy or revelation, within the aesthetic secular realm of musical avant-garde and modern Hebrew literature. By focusing on two case studies, I attempt to shed new light on the question of Jewish secular culture. Arnold Schoenberg (1874-1951), an Austrian Jewish composer, was born into an assimilated Viennese family and converted to Protestantism before returning to Judaism in the 1930s while escaping to the United States. Aharon Appelfeld (1932-2018), an Israeli Jewish writer, was born in Czernowitz to assimilated German-speaking parents, survived the Holocaust and emigrated to Israel in 1946. My claim is that in their works both composer and author testify to traumatic experiences that avoid verbal representation by: (1) subverting and transgressing conventional aesthetic means and (2) alluding to sacred tropes and theological concepts. In exploring Schoenberg's opera Moses und Aron and Appelfeld's Journey into Winter among others, this article shows how the transcendent sphere returns within the musical and poetic avant-garde (musical prose, 12-tone composition, prose poem, non-semantic or semiotic fiction) as a "sound" of old traditions that can only be heard through the voices of a new Jewish culture.
\end{abstract}

Keywords: Arnold Schoenberg; Aharon Appelfeld; religiosity; Jewish secular culture; Moses und Aron; modern Hebrew literature

\section{Introduction}

In his 1915 essay "Revealment and Concealment in Language" the modern Hebrew poet Haim Nahman Bialik marks a borderline by distinguishing between two different modes of representation: verbal and non-verbal languages. Among the non-verbal are "those languages without words: songs, tears, and laughter". What is revealed on the borderline between the non-verbal and the verbal, where the word is devoid of semantic content and becomes pure sound? According to Bialik, "these languages begin where words leave off, and their purpose is not to close but to open. They rise from the void. They are the rising up of the void. Therefore, at times they overflow and sweep us off in the irresistible multitude of their waves; therefore, at times they cost a man his wits, or even his life." Only pre-languages can bear witness to this void, a dangerous realm that reverberates with horror and death. At the same time, however, "every creation of the spirit which lacks an echo of one of these three languages is not really alive" (Bialik 2000, p. 26).

The issue of the non-representational has a long history that reached a peak in German Romanticist thought. Bialik's essay thus follows a wide tradition of poets and philosophers such as Wilhelm Heinrich Wackenroder, Novalis, Arthur Schopenhauer and Friedrich Nietzsche, to name only a few. All of them demonstrate various ways of transforming theological tropes and transcendental concepts into the aesthetic realm-poetic and musical. Wackenroder, for instance, based his music theory, which was later associated with the concept of "absolute music" (Dahlhaus 1978), on the idea that the non-semantic art of sounds creates an intimate link to areas that were hard to capture with words, 
such as emotions and transcendental spheres. Unlike literature, music does not have to describe these areas with words that always fall short of the object they refer to. In "absolute music", a symphony, for example, gives listeners emotional insight into and access to divine spheres by letting them experience what cannot be described. Being linked to the "absolute", music even becomes a new religion, a "Kunstreligion" (Martinec 2018, p. 129).

Here, however, lies the danger of music, as conveyed, for instance, through the singing of the mythological sirens. An act of violence to which the listener must surrender, for the soul is incapable of resisting its sensual temptations, music also embodies a powerful threat: elevation and surrender become two sides of the same coin (Caduff 1999, p. 247). A version of this notion is expressed by E. T. A. Hoffmann, who claimed that "Beethoven's instrumental music opens to us the realm of the monstrous and immeasurable. Glowing rays shoot through the deep night of this realm, and we sense giant shadows surging to and fro, closing in on us until they destroy us" (Locke and Hoffmann 1917, p. 128). Other versions are known from Arthur Schopenhauer and Friedrich Nietzsche, which greatly influenced Romanticist and post-Romanticist writers.

I do not aim to explore the extensive work on the philosophical-aesthetic aspects of the non-representable, either in German or in Hebrew. Rather, I wish to examine the use of central elements of the Jewish religious repertoire and transcendental realm, such as prophecy or revelation, within the aesthetic secular realm of musical avant-garde and modern Hebrew literature. By focusing on two case studies, this article attempts to shed new light on the question of Jewish secular culture. The first is Arnold Schoenberg (1874-1951), an Austrian Jewish composer, who was born into an assimilated Viennese family, and converted to Protestantism, before returning to Judaism in the 1930s. During the Third Reich, Schoenberg fled to the United States, where he remained for the rest of his life. The second is Aharon Appelfeld (1932-2018), an Israeli Jewish writer born in 1932 in Czernowitz to assimilated German-speaking parents. After surviving the Holocaust, he emigrated to Israel in 1946 where he lived as a writer until his death.

My claim is that in their works, both composer and author testify to traumatic experience that avoids verbal representation by: (1) subverting and transgressing conventional aesthetic means and (2) alluding to theological tropes and transcendental concepts. Written in a world that went through extensive processes of secularization, their works are detached from religious practices and rituals, and not a part of Jewish liturgy. However, by transforming elements associated with the Jewish sacred realm into the non-religious creation, they reveal something about the unspoken nature of a secular Jewish culture. The opera Moses und Aron (1926-1932) demonstrates Schoenberg's preoccupation with Jewish topics, partly in response to anti-Semitic incidents. Based on an innovative compositional system that Schoenberg developed in the 1920s, this opera explores the issue of the unpresentable God through the character of the biblical tongue-tied prophet, Moses. Appelfeld's novel A Journey into Winter (2000), among others, bears witness to his painful experiences during the Second World War-his expulsion together with his father to a labor camp, his mother's murder, his escape and survival in the Ukrainian forests until his immigration to Israel. As in other prose texts by Appelfeld, in this novel, the literary character stutters. How can this linguistic flaw, which recurs in both Schonberg's music and Appelfeld's prose, be explained? Is this only a thematic issue, or is it an integral part of a poetic syntax and a musical structure?

Gilles Deleuze defines different modes of stuttering in fiction by distinguishing between speech and language. While the first mode is conveyed through an explicit depiction of stuttering characters and the second suggests an implied depiction of the characters, a third mode, as the reader indirectly learns about the stuttering, can be found by writers, who, according to Deleuze, placelanguage "endlessly in a state of disequilibrium, they cause it to bifurcate and to vary in each one of its terms according to a ceaseless modulation [... ] all this goes beyond the possibilities of speech" (Deleuze 2000, p. 23). Furthermore, this mode creates infinite variations that fracture the verbal system from within, pushing it to its limits: "It is when the language system overstrains itself that it begins to stutter, to murmur, or to mumble [ ... ] It is a painting or a piece of music, but a music of words, a painting with words, a silence 
within words, as if words were not disgorging their content—a grandiose vision or a sublime audition" (Deleuze 2000, p. 28). Deleuze's alluding to music when defining how a poetic language stutters is unsurprising; stuttering conveys the music of a literary text. In light of the Romanticist notion, this music becomes a means of a secular literary repertoire to reverberate with sacred transcendental realms that avoid verbal representation.

Maurice Blanchot, for his part, explores similar issues of verbal representation as they are associated with the notion of disaster: "The disaster, unexperienced. It is what escapes the very possibility of experience-it is the limit of writing. This must be repeated: the disaster de-scribes. Which does not mean that the disaster, as the force of writing, is excluded from it, is beyond the pale of writing or extratextual" (Blanchot 1992, p. 7). Focusing on the writing of which the disaster is both a limit and a force, Blanchot points to the way language ceases to signify stable meanings. Instead, its components begin to drift into the indeterminacy of multiple meanings, while bringing to the surface an "absent meaning" (p. 41). Similar to the ceaseless modulation mentioned by Deleuze, this movement too-an "absolute disruption which admits of no regimen, region, regulation, direction, erection, insur-reaction" - turns every subject, text, historical narrative, or political system ceaselessly outside itself, toward the radical alterity of otherness: “Outside. Neutral" (pp. 56-57). Pushing the limits of language while escaping any closure, totality and unity, also means silence, which, however, reverberates with the unsayable: "the silent outside, in the silence of silence which by no means has any relation to language for it does not come from language but has always already departed from it-in this silent exteriority, that which has neither begun nor ever will finish, keeps watch: the night" (p. 57).

How is this movement of stuttering which culminates with the soundless (silence) and imageless (night) conveyed? What role does it play in a (secular) musical repertoire that testifies to the disaster? Focusing on the work of Schoenberg before moving to that of Appelfeld suggests a few answers to the questions raised above.

\section{Schoenberg's Music between Tradition and Avant-Garde}

Arnold Schoenberg was born in Vienna in 1874 to an assimilated Jewish family. In 1898 he was baptized in the Lutheran church. Shortly thereafter he moved to Berlin where he met Richard Strauss, and earned his living by teaching composition. On returning to Vienna he became acquainted with Gustav Mahler, and also founded the Second Viennese School. Following his appointment as head of the Prussian Academy of Arts in 1925, Schoenberg returned to Berlin, and was forced to resign in 1933 when the Nazis came to power. He fled from Germany through France to the United States, where he lived until his death in 1951. While in Paris, because of his engagement with the Jewish community, Schoenberg returned to Judaism.

I suggest listening to his opera Moses und Aron, composed between 1926-1932, in light of this life experience, and how his preoccupation with the issue of Jewish identity is embodied in his musical history. ${ }^{1}$ In 1921, while in Maatsee, a town near Salzburg, Schoenberg was asked to leave the resort because of his Jewish descent. In his letter to Wassily Kandinsky from 1923 declining the painter's offer to join the Bauhaus after hearing that other members of the School were anti-Semitic, he writes sarcastically: "For I have at last learned the lesson that has been forced upon me during this year, and I shall not ever forget it. It is that I am not a German, not a European, indeed perhaps scarcely a human being (at least, the Europeans prefer the worst of their race to me), but I am a Jew" (Schoenberg 1958, p. 90).

Haunted by this experience, Schoenberg worked it through in the aesthetic realm as demonstrated by various compositions, such as: Der bibliche Weg (1926-1927), whose protagonist alludes to the historical character of Theodor Herzl, or Vier Stücke für gemischten Chor (1925). He elaborated the latter

1 For a discussion of Schoenberg's Jewish identity see (Mäckelmann 1984), (Ringer 1990), (Goldstein 1992). Edward (Latham 2000) focuses on the opera Moses und Aron, while showing how the religious ideas expounded in the musical piece demonstrate Schoenberg's Mosaic view of his purpose as a Jew and an artist. 
into an oratorio in 1928, which also became the basis for his opera Moses und Aron, which he never completed. Of the three acts that Schoenberg wrote, he composed only two. The libretto is based on two books of the Bible in Luther's translation: Exodus 3-4, 17, 20-31, 32; and Numbers 20, 24. ${ }^{2}$ Among Schoenberg's works which explicitly deal with Jewish themes are also Die Jakobsleiter (1915-1917), Kol nidre für Sprecher (Rabbi), gemischten Chor und Orchester (1938), A Survivor from Warsaw for Narrator, Men's Chorus and Orchestra (1947), Psalm 130 for Mixed Chorus a cappella (1950) and Moderner Psalm für Sprecher, gemischten Chor und Orchester (1950). Referring to A Survivor from Warsaw, Schoenberg wrote in 1948 to Kurt List:

The Shema Jisroel at the end has a special meaning to me. I think, the Shema Jisroel is the 'Glaubensbekenntnis,' the confession of the Jew. It is our thinking of the one, eternal, God who is invisible, who forbids imitation, who forbids to make a picture and all these things, which you perhaps have realized when you read my Moses und Aron [... ] The miracle is, to me, that all these people who might have forgotten, for years, that they are Jews, suddenly facing death, remember who they are (Schoenberg 1988, p. 105).

Here, Schoenberg alludes to Shema Yisrael, which is considered by observant Jews as the most important part of the prayer service in Judaism. The first verse encapsulates the monotheistic essence

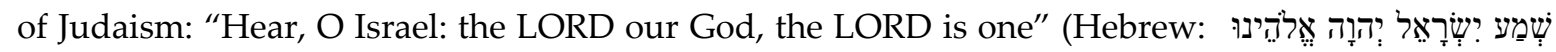
יניהוה אחד: , found in Deuteronomv 6:4. The Jew's confession of belief in the One and Onlv God, which rejects visual representation, is transmitted through the sound (the command: "Hear"). In Schoenberg's musical avant-garde this point becomes crucial.

Schoenberg's letter to Anton Webern shows how he connects with the actual "reconversion" and specific musical compositions, the relationship between the aesthetic and the religious, the innovative and the traditional, which interested Schoenberg since the 1920s. ${ }^{3}$ These are precisely the years when his path-breaking innovation took place, the development of the 12-tone technique. In "Composition with twelve tones", a lecture delivered at the University of California, Los Angeles in 1941, Schoenberg defined the innovative technique based on four tonal rows: Basic Set (Grundreihe), Inversion (Krebs), Retrograde (Umkehrung) and Retrograde Inversion (Krebs der Umkehrung), in which every tone of the musical row must appear once before it reappears (Schoenberg 1975, p. 115). The lecture opens with the analogy between the musical creation and the Divine creation (Genesis), and between the Divine (God) and the human (musician) creator:

To understand the very nature of creation one must acknowledge that there was no light before the Lord said "Let there be Light". And since there was not yet light, the Lord's omniscience embraced a vision of it which only His omnipotence could call forth [ ... ] In fact, the concept of creator and creation should be formed in harmony with the Divine Model; inspiration and perfection, wish and fulfillment [... ] in Divine Creation there were no details to be carried out later [ ... ] Alas, human creators, if they be granted a vision, must travel the long path between vision and accomplishment (Schoenberg 1975, p. 102).

Emphasizing the rift between the vision and its accomplishment echoes Schoenberg's own aesthetic innovation, as the allusion to the sacred sphere (Divine) goes beyond a simple parallel. Rather, this is the aesthetic means, the style, which bears witness to the transcendent idea-the innovative musical technique, which embodies a non-representable content. Like the biblical prophet Moses from the opera, the modern composer Schoenberg speaks about the limitations through which the non-representable is revealed.

The piano pieces op. 23 and op. 25 composed between 1920-1923 are regarded as the first musical pieces based entirely on the innovative technique. The opera Moses und Aron is also based on this

2 On the textual sources of Schoenberg's libretto see, for instance, (Steck 1981); (Goldstein 1992), (Berry 2008).

3 On this interrelation compare with (White 1985), (Ringer 1990), (Goldstein 1992), (Latham 2000), (HaCohen 2006). 
technique. This development was a part of a wider trend of dealing with the classical conventions of music, which seemed to have reached a dead end. Together with his students, members of the Second Viennese School, Schoenberg questioned the limits of classical conventions of harmony and tonality: the "emancipation of the dissonance", the free tonality or atonality, and the 12-tone composition. However, as demonstrated by this modernist opera, Schoenberg uses these innovative means of the musical avant-garde he developed in order to express ideas related to the sacred tradition and theological sphere, such as prophecy and revelation, and to the idea of the non-representable monotheistic God. Among these means is the 'Sprechgesang', a combination of singing and speaking, which Schoenberg first used in 1908 in his atonal compositions.

A further means is a texture Schoenberg called "musical prose", which he already detected in the works of the First Viennese School, such as Hayden and Mozart, or in Brahms and Mahler, and radically elaborated (Daunser 1997, pp. 864-66). Due to its asymmetric textures, the "musical prose" provided a true relation to reality without hiding its contradictions under symmetric and therefore "false" (deceptive) structures. Furthermore, in his lecture on Brahms's anniversary in 1933, Schoenberg claimed:

Great art must proceed to precision and brevity [ . . ] This enables a musician [ . . ] not only doing what grammar, and idiom require, but in other respects lending to every sentence the full pregnancy of a meaning, of a maxim, of a proverb, of an aphorism. This is what musical prose should be-a direct and straightforward presentation of ideas, without any patchwork, without mere padding and empty repetitions (Schoenberg 1975, p. 415).

The concept of truth embodied in the "precision and brevity" of great art, and the "direct and straightforward presentation of ideas", recurs in the opera in the conflict between the brothers Moses and Aaron. Each suggests a different mode of representing the idea of the monotheistic God. According to Moses, who stands at the center, the visual image is false and the word, which he, however, lacks, is true.

Theodor Adorno explored this conception in Philosophy of Modern Music. He points to Schoenberg's bonding of music and truth on the one hand, and to music and necessity, on the other, by quoting from the latter's theoretical writings: "Music is not to be decorative; it is to be true", and "Art does not arise out of ability but rather out of necessity" (Adorno 2004, p. 41). ${ }^{4}$ Whether or not he was correct about Schoenberg's perspective on the pictorial character of music that finally succumbed to Adolf Loos's verdict "ornament is a crime", Adorno points out the strong correlation between the musical-aesthetic and the religious-philosophical aspects in Schoenberg's music in general, and Moses und Aron in particular. ${ }^{5}$

In his essay "Sacred Fragment", which focuses on this opera, Adorno claimed that the essential relationship between music and Judaism lies in their resistance to the image and their rejection of visual representations: "The Jewish prohibition on making images which forms the center of the text, ${ }^{6}$ also defines the approach of the music $[\ldots]$ the imageless art $[\ldots]$ that is no doubt the key to the relationship between Judaism and music" (Adorno 2002, p. 230). The image prohibition thus reveals the dilemma connected to the possibility and non-possibility of representing the monotheistic God. The clash between the aesthetic quest for form and the magnitude of the divine constitutes the inner formal logic of Schoenberg's biblical opera. Despite Adorno's critique by pointing to Schoenberg's metaphysical, aesthetic and political "errors" (Hanssen 2006, pp. 192-94), this opera demonstrates an attempt to trace the Jewish sacred within the realm of a modernist secular work. By inquiring

4 Whereas the second reference is found in Schonberg's Musikalisches Taschenbuch II, 1911, p. 22, the first could not be traced. See (Floros 2011, p. 259).

5 Adorno (2002, p. 230) refers to Adolf Loos's 1908 pamphlet Ornament and Crime.

6 Here, Adorno alludes to the second commandment of the Ten Commandments from Exodus: "Thou shalt not make unto thee any graven image, or any likeness of anything that is in heaven above, or that is in the earth beneath, or that is in the water under the earth". 
into these questions, Schoenberg's avant-garde opera becomes an aesthetic laboratory of an ethical exploration of the limits of representation in general, and of God's presence in particular.

Since the second half of the 20th century, this exploration has become an integral part of the discourse regarding the non-representability of the catastrophe of the Second World War and the Holocaust (Steiner 1967, p. 139; Hanssen 2006, pp. 195-97).

The question of the imageless monotheistic God, as an "advance in intellectuality", also stands at the core of Sigmund Freud's essay Moses and Monotheism, written in the 1930s and first published in 1939.7 According to Freud, Judaism emerged from the dialectics of oblivion and memory caused by a traumatic event-the murder of Moses, the monotheistic lawgiver-which was repressed and later returns in a new form: "When Moses gave to his people the conception of an Only God it was not an altogether new idea, for it meant the reanimation of primeval experience in the human family that had long ago faded from the conscious memory of mankind. The experience was such an important one, however, and had produced, or at least prepared such far-reaching changes in the life of man that [ ... ] it must have left some permanent trace in the human soul—something comparable to a tradition" (Freud 1967, 167). This early trauma accounts for both the oedipal dispositions of the human soul and the cultural development of religion and morality. As Assmann contends, "monotheism, according to Freud, was a kind of return of the repressed [ ... ] Moses' monotheism was the return of the father" (Assmann 2006, p. 11). In light of this, the silencing of that which has been denied, namely the Bible's silence about the murder, reverberates with Moses' speech disabilities. The lawgiver's deconstructed language embodies the double effect of repression in Jewish tradition, which resonates in Schoenberg's music.

Yosef Yerushalmi also elaborates on this silence. While pointing to Freud's own silenced (life) story, namely his denial of Jewish identity and his familiarity with the Hebrew (biblical) language, he concludes his imagined monologue: "I think that in your innermost heart you believed that psychoanalysis is itself a further, if not final, metamorphosed extension of Judaism, divested of its illusory religious forms but retaining its essential monotheistic characteristic [ ... ] I think you believed that just as you are a godless Jew, psychoanalysis is a godless Judaism. But I don't think you intended us to know this" (Yerushalmi 1991, p. 99). However, in Derrida's view, Yerushalmi's hypothesis about Freud's secret points to his own secret—-the silence of the historian who decides to "'step aside' [ ... ] to let a photographic specter or Freud's phantom in the monologue speak [ ... ] as a sign of a respect before the future to come" (Derrida 1998, p. 70).

This layered identification with Moses (Derrida 1998, p. 67) is manifested in Schoenberg's case as well. However, how is the muted, concealed content, which is outside of language, revealed? Similar to Freud, who in the face of growing anti-Semitism writes about the collective trauma at the core of Jewish religion, Schoenberg composes the non-representability of the monotheistic God. Whereas Freud applies the secular science of psychoanalysis and modern philology, while using the "return of the repressed", namely the old that recurs anew, Schoenberg applies the secular aesthetics of music and modernist opera, while tracing the tradition conveyed throughout the avant-garde. Schoenberg and Freud both focus on the role of Moses, the tongue-tied prophet, in the formation of Judaism. Yet, despite the similarities, Ruth HaCohen shows how their narratives differ, not only because Schoenberg rejects the Oedipal plot, ${ }^{8}$ but also because of his breaking away from the German history of music, namely a 200-year period of oratorical-operatic tradition (HaCohen 2006, pp. 190-93).

7 In Der Mann Moses und die monotheistische Religion (1939), Freud's last major work and the only one devoted specifically to a Jewish theme, Freud claims, among others, that Moses was an Egyptian, that he derived the notion of monotheism from Egyptian concepts, and that after he introduced monotheism to the Jews, who proved incapable of withstanding the hardships of this religion, murdered him and subsequently repressed the deed. Freud's historical and ethnographic assumptions have generally been rejected by biblical scholars, anthropologists and historians of religion. Nevertheless, his book has increasingly been approached psychoanalytically as a psychological account of his own life. For further scholarship see (Slavet 2008).

8 At the end of the third act, when Aaron, who comes on stage as a prisoner in chains, is finally set free, he falls down dead. Accordingly, this opera embodies the death of the brother rather than the father. 


\section{Lacking Words: Prophetic Inheritance in Moses und Aron}

The issue of representing an event or an idea by means of alternative sign systems, such as verbal, visual or acoustic, is central to Moses und Aron, which alludes, among others, to works by Karl Kraus and Arthur Schopenhauer. ${ }^{9}$ Schoenberg's opera explores the question of the law inherent in the sacred realm and as conveyed through the concept of the monotheistic God (the Ten Commandments). ${ }^{10}$ Based on the events described in Exodus, the opera tells the story of the biblical brothers. In the first scene of the first act, Moses is called to lead the people of Israel out of Egypt. He has to convince them to trust the One and Only God, whom they can neither see nor hear. Moses refuses to accede to this call, claiming that he is incapable of fulfilling the mission due to his "slow tongue". In response, he is promised that his brother, Aaron, will stand by his side and be his "mouth". The second scene exposes the first conflict between the two brothers due to their different perspectives. Whereas Moses adheres to the idea of the non-representable God that must not be transmitted through visual images, Aaron insists on the impact of a concrete mediation to make the people believe in the power of the monotheistic God. This primal scene culminates in the partial success of the original mission. Thanks to various miracles enacted by Aaron, the people agree to follow the "new" God in their desert journey. The first act ends with their arrival in the desert, just as Moses is about to ascend Mount Sinai to receive the religious laws.

The second act opens with the Israelites' discontent and impatience waiting for Moses. 40 days have passed and Moses has not yet appeared. Aaron is urged to provide them with an alternative-a desired image, whose concreteness replaces the abstract idea of the One and Only God. The non-representable God is thus replaced with the golden calf. The new object of worship is placed in the center of a permissive ritual presented on the opera stage, a scene filled with anarchy, disorder and violence, including rape and murder. When Moses finally descends from Mount Sinai he is horrified by what he sees. He rages and blames Aaron for betraying their mission. Their conflict now reaches another level.

In contrast to the second scene of the first act in which speaking simultaneously the brothers hardly hear each other, in the fifth scene of the second act, they do speak to one another. This dialogue, however, exposes the insoluble differences between them. During their charged dispute Moses shatters the stone tables he received on the mountain. The scene ends with Moses alone on stage; the people and Aaron have disappeared. A final witness to what has occurred, he, the stutterer whose tongue is tied, admits defeat while lamenting the lack of words. What is the significance of the verbal lack that connects the concept of the non-representable God and the prophet's stuttering? And how is this lack of an appropriate representational mode conveyed through the musical language? The first words heard on stage are those of Moses, followed by the revelation of God in the Burning Bush. Moses' words serve as the motto of the whole opera: "Only one, infinite, thou omnipresent one, unperceived and inconceivable God" (Einziger, Ewiger, Allgegenwärtiger, Unsichtbarer und unvorstellbarer Gott!), (Schoenberg 1984, p. 8). ${ }^{11}$ God is characterized as the one and only, which emphasizes the revolutionary aspect of monotheism relative to the polytheistic religions. Other characteristics are the infinity of God, his omnipresence and finally the inability to conceive and perceive him. The slow tempo of Moses' vocal assertions expands the space between the letters that build the words, thereby delaying their semantic meaning. As a consequence, the listener oscillates between the content of the utterance (what is said) and the performative style (how it is said), and between the semantic and the semiotic aspects of language. In terms of music, Schoenberg subverts both the rules of classical tonality and of operatic singing style. This deviation from the aesthetic convention generates two musical innovations: first, the 12-tone composition, and second, the Sprechgesang. The opera demonstrates a parallelism between

9 On the intertextual relations of Schoenberg's opera to philosophical and aesthetic sources, see (Covach 1996).

10 For a detailed discussion of the God-Idea as it is conveyed in Schoenberg's work, including in his opera Moses und Aron, see (White 1985), (Latham 2000).

11 In this article I refer to the (libretto's) English translation by Allen Forte. 
two realms of transgression - the sacred (the innovative idea of a monotheistic God) and the secular (the innovations associated with modern music), as the transcendence in the divine sphere is conveyed through the deviation from classical conventions of the aesthetic work. For instance, in the first scene, the transcendental moment of God's revelation through the Voices of the Burning Bush (die Stimme aus dem Dornbusch) is responded to by the voice of Moses. Both voices are composed and performed in the innovative style of Sprechgesang, which deviates from classical music conventions. Like the voice of the prophet, the voice of God cannot be defined or attached to a stable tonal spectrum-rather, they "stutter". In light of Deleuze's and Blanchot's notion of language, I claim that Schoenberg sets these voices in an endless state of disequilibrium, causing them to bifurcate and to vary in ceaseless modulation, and therefore to oscillate between the speaking and the singing, like the voices of a "third", Neuter, that stutters.

However, what is the content of this stuttering, and how is the relation between style and idea to be understood? As pointed out above, the voices from the burning bush demand obedience from Moses. He is asked to lead the people out of Egypt to their own land by convincing them to put their trust in the monotheistic God. Moses' answer affirms his physical deficiency: "But my tongue is not flexible. Thought is easy; Speech laborious" (meine Zunge ist ungelenk. Ich kann denken, aber nicht reden), (Schoenberg 1984, pp. 16-17). The response soon follows: "Aaron will be enlightened; he shall be your mouth! From him will your own voice then issue, as from you come my voice!" (Aron will ich erleuchten, er soll dein Mund sein! Aus him soll deine Stimme sprechen, wie aus dir die meine!), (Schoenberg 1984, pp. 19-20). Schoenberg connects the "problem" of the non-representable God with the "problem" of the stuttering prophet. Thus, the difficulty of understanding Moses' speech, since he lacks words, correlates highly with the difficulty of conceiving the idea of an abstract God that should not be conveyed through concrete images (the prohibition of the image). Moses' stuttering, however, is not only that of speech, but also of language as a system-verbal and musical.

Musically, Schoenberg creates a metonymic relation between the idea and the style: Moses, the prophet who is responsible for the expression of the idea and its mediation to the people, becomes an extension of the idea he has to transmit. Both are characterized by an extreme rejection of convention-on the one hand, the transcendental presence of the monotheistic God that negates concrete perception, and on the other, the stuttering of the prophet that subverts standard language. As pointed out above, Schonberg elucidates these two events- the revelation of God through the burning bush and the prophecy of Moses-by means of innovative, modernist music: a hybrid voice between singing and speaking (Sprechgesang) and a deviation from tonal centers (12-tone technique). The theological figures of revelation and prophecy are thus transformed through innovative aesthetics into the secular musical work.

The second scene presents a further example of the relationship between the sacred and the secular, the theological and the aesthetic in Schoenberg's work. As mentioned, the mediation of God's words to the people is inherent in the question of representing the non-representable, imageless God. For each brother, the relationship between God and His people embodies different elements. Whereas Moses speaks of obedience to the laws of God by emphasizing the virtues of truth and justice, Aaron emphasizes the virtues of love and worship. Furthermore, in Aaron's view, in order to love you have to imagine and to see whom you love. Moses' response is firm, demanding uncompromised acknowledgment and recognition of an unconceivable God. The scene ends with Moses' and Aaron's simultaneous expression. In their musical duo, each expresses to the people his own conception of the mediation of God's presence. Against the "law of thought" (Denkgesetz) which demands obedience, Aaron suggests a devotion based on love, and worship that comes from knowing that you are chosen: 
Aron:

Auserwältes Volk, einen einzigen Gott ewig zu lieben mit tausendmal mehr der Liebe, mit der alle andern Völker ihre vielen Götter lieben. Unsichtbar! Unvorstellbar! Volk, auserwält dem Einzigen, kannst du lieben, was du dir nicht vorstellen darfst? (Schoenberg 1984, pp. 38-42)

Moses:

Darfst? Unvorstellbar, weil unsichbar; weil unüberblickbar;

weil unendlich; weil ewig; weil allgegenwärtig; weil allmachtig. Nur einer ist allmächtig. (Schoenberg 1984, pp. 42-43)
Aaron:

Chosen is this folk,

Thus to love one great God for ever and ever, With a thousand times more devotion Than all other earthly peoples for their many Godly beings. Not be seen, not imagined.

Folk chosen by the only one, can you Worship what you dare not even conceive?

Moses:

Dare not? Not conceived because unseen. can never be measured, everlasting, eternal, because ever present, and almighty.

The one God is almighty.

The distinction between the concrete image (Aaron) and the abstract idea (Moses) is conveyed through the use of different musical styles: Aaron's tenor part is highly melodic, like the Bel Canto style of 19th century opera arias, whereas Moses' bass part is a Sprechgesang. These contrasting musical styles create a semantic dichotomy between musical convention and a deviation from this convention, and between traditional and innovative styles. In light of the conflicting plot, these two musical traditions demonstrate opposing ethical approaches to the issue of representing the monotheistic God: the false, deceptive representation ('Bel Canto') associated with the visual image of Aaron, in contrast to the true, authentic representation (Sprechgesang) associated with the incomplete word, that is, the unstable stuttering language of Moses. ${ }^{12}$ Schoenberg's aesthetic demand of a "direct and straightforward presentation of ideas, without any patchwork, without mere padding and empty repetitions" (Schoenberg 1975, p. 415) thus gains additional meaning. A true aesthetic is required for a true representation of that which is beyond speech and image, the non-representable that reveals as the unsayable.

As the opera shows, both approaches demand heavy prices from their proponents. This is demonstrated in the last scene of the opera's second act, in which each brother is fighting for his truth:

Moses:
Unvorstellbarer Gott!
Unaussprechlicher, vieldeutiger Gedanke!
Lässt du diese Auslegung zu?
Darf Aron, mein Mund, dieses Bild machen?
So habe ich mir ein Bild gemacht,
falsch, wie ein Bild nur sein kann!
So bin ich geschlagen!
So war alles Wahnsinn, was ich gedacht habe,
und kann und darf nicht gesagt werden!
O Wort, du Wort, das mir fählt! (Schoenberg 1984, pp. 500-2)
Moses:

Unconceivable God!

Inexpressible, many sided idea!

Will you let it be so explained?

Shall Aaron, my mouth, fashion this image?

Then I have fashioned an image too,

False, as an image must be!

Thus am I defeated!

Thus, all was but madness that I believed before, and can and must not be given voice!

O Word, thou Word that I lack!

Aaron emphasizes his love for the people, whereas Moses emphasizes his devotion to the idea of monotheistic law. When Aaron mentions that the tablets with the Ten Commandments include images as well, Moses smashes them to the ground. The fractions can no longer be integrated into a whole, which is now missing, like the missing words that Moses points to: "O Word, thou Word

12 Compare with Elliott Gyger (2007, p. 438): "Moses und Aron is a strange beast indeed: an opera in which not only does the protagonist does not sing, but the very act of singing itself can become morally suspect". 
that I lack!" (O Wort, du Wort, das mir fehlt!), (Schoenberg 1984, p. 502). The image (Bild) Aaron provided to Moses, or rather the people, is a false image, "as an image must be", one that distorts the idea and the laws of the monotheistic God. Moses lost the battle, and failed to complete his mission. Thus, the incomplete word of the stuttering prophet becomes itself a site of revelation in the aesthetic realm of a secular work. In the 1930s when Schoenberg left his opera uncompleted, the catastrophe of the people of Israel, embodied in Moses' lamentation, can no longer be separated from the catastrophe of the Jews in Europe and beyond. Moreover, in light of German musical history from Bach's St. Matthew Passion, through its revival by Felix Mendelssohn, and in its oratorios Elijah and St. Paul-and climaxing in Wagner's Parsifal, which is based on a Jewish-Christian debate concerning redemption, compassion, and negative theology, Schoenberg's opera seems to embody rapture. As HaCohen claims, in re-assassinating the compassionate leader (Jesus/Aron), namely in killing the son, whose permanent sacrificial being, functioned as a means of redemption, instead of killing the father (Moses), Schoenberg breaks the tradition. From that point onward he no longer views himself as a German composer (HaCohen 2006, p. 193). In this sense too, Schoenberg's return to the old biblical story of the stuttering prophet within an innovative aesthetics of music, reveals and at the same time reclaims the Hebrew liturgical values that were concealed and appropriated by the German translation.

To briefly conclude: at the level of the plot, the missing word stands for the prophet being tongue-tied. This feature, however, demonstrates Moses' proximity and closeness to the holy realm of the transcendental, since no word or image can represent that which relates to this realm. The prophet with his Sprechgesang is an extension of the sacred presence in the aesthetic realm. Stuttering itself reveals a borderline between the immanent and that which transcends beyond. Schoenberg expresses this transcendence with innovative music: first, the 12-tone composition based on rigorous principles of tonal rows and rejecting repetitions, which radically challenges classical tonality and harmonic conventions of music; and second, the hybrid style of the Sprechgesang, which deviates from classical conventions of opera singing (the classical aria or the Bel Canto style).

Finally, Schoenberg's decision to shape central characters of the opera according to the biblical prophet who was not allowed to enter the Promised Land reveals something about his own identity processes and self-understanding as a modernist, path-breaking, composer. ${ }^{13}$ He never completed this opera, which combines both the mythical and the poetical, and the theological and the historical. However, this ostensible "flaw" embodied in an "incomplete whole", like the verbal flaw of the stuttering prophet, reverberates with that which arises from the bubbling abyss. Precisely this fault bears witness to loss and absence, which can no longer be repaired. ${ }^{14}$

\section{Appelfeld's Fiction on the Threshold of Old and New}

In his memoir The Story of a Life, Appelfeld described his path into writing. While physically working the land in Nahalal, an agricultural village, he began to write Hebrew by copying biblical letters. He describes the acquisition of the new language as a painful process of losing German, his mother tongue, and as part of this process, a deep feeling of guilt that was expressed in symptomatic stuttering. Emigration to Israel after having survived the Holocaust is experienced as an irreparable rift for the writer, who is traumatized by the war and haunted by the murder of his mother. Appelfeld works through this trauma in his fiction by bringing to life the old world of his parents and his grandparents, and of Jewish experience before and after the Holocaust in both Europe and Israel. As opposed to Nahalal, where he first started to write Hebrew, Appelfeld writes about the Carpathians, his grandparents' homeland:

I come from an assimilated home that had not a trace of religious belief. There was plenty of serenity and attentiveness, and we all treated one another with sensitivity—but it was all

13 For Schoenberg's identification with his operatic characters see: (Hanssen 2006), (HaCohen 2006), (Auner 2007).

14 On the fragment as a whole see (Steiner 1967, p. 139). 
done on a rational basis. Formal religion was thought to lack real feeling; it was considered vulgar and ill-conceived [ ... ] I loved Grandfather and Grandmother's village, their spacious wooden house, the acacia trees growing next to it [ ... ] there was a mystery in everything. It was not surprising that I felt that God dwells only in the countryside. In the village I would walk with Grandfather to the synagogue, listen to the prayers, and gaze at the wooden lions above the Ark that housed the Torah scrolls (Appelfeld 2004, p. 121).

In reviving not only the assimilated secular world of his parents, but also the religious world of his observant grandparents, Appelfeld placed himself outside the hegemonic culture that was emerging in the formative statehood years in Israel: "During the late 1950s, I gave up my ambition to become an Israeli writer and made every effort to become what I really was: an émigré, a refugee, a man who carries within him the child of war, who finds talking difficult and tries to speak with a minimum amount of words. This effort culminated in my first book, Smoke, which appeared in 1962" (Appelfeld 2004, p. 124). Appelfeld writes about these worlds, which were experienced in German, among other "foreign" languages. His decision to write in Hebrew can be explained by the fact that Appelfeld was torn from his parents and his mother tongue around the age of eight. However, an additional explanation that drove Appelfeld to look elsewhere, was the need to find a new language alternative to those languages that betrayed human values. ${ }^{15}$

This need recurs in his essays "Testimony" and "Beyond the Tragic", in which he admits to a lack of words in the face of a false, deceptive language. That which could not be expressed by the given or common modes of expression, had to wait for the discovery of a new language. ${ }^{16}$ Seeking to represent the non-representable, that is to say, to give voice to the unsayable, Appelfeld returns to the old Jewish prayers that recur within a modernist literature. His secular prose thus reverberates with the form and content, and with the style and idea of Jewish religiosity, and hence can be perceived as a fiction emerging on the threshold of the old and the new.

Similar to Schoenberg, Appelfeld's work is extensively situated in various contexts. ${ }^{17}$ Two of these contexts, which for some scholars are interrelated, are particularly relevant for our discussion: first, the relation of Appelfeld's literature to the Holocaust and the catastrophe of the Second World War, and second, his attitude towards religion. Regarding the first, Hillel Barzel (1981)was among the first scholars to suggest a typological reading of Appelfeld's representation of the Holocaust. Like Dan Miron (1979), Gershon Shaked (1985) also pointed out the complex relation (beyond categories of realism and symbolism) of Appelfeld's work to this historical event. The author, for his part, rejected the label "Holocaust writer":

"I was a child during the war. This child grew up and all that happened to him and within him continued into his adulthood: the loss of his home, the loss of his language, suspicion, fear, the inhibitions of speech, the feelings of alienation in a foreign country. It was from these that I wove my fiction. Only the right words can construct a literary text, not subject matter" (Appelfeld 2004, pp. 124-25).

Like Schoenberg's demand for true expression, Appelfeld distinguishes between different ways of writing, while contending that "a writer, if he's a writer [ ... ] he's faithful to himself-to his voice and his rhythm" (Appelfeld 2004, p. 124).

According to Emily Budick (2005), because it is fiction, Holocaust fiction challenges the tradition of writing about this event, rather than as history, documentary, or memoir. Focusing on Appelfeld's

15 Issues of translingualism in Appelfeld's literature are discussed by various scholars. On bilingualism and the relation between Hebrew and Yiddish, see for example (DeKoven Ezrahi 2000), (Sokoloff 2005), (Pinsker 2014). On the relationships between Hebrew and German, see (Ben-Horin 2018).

16 In these essays Appelfeld (1979) points to three sources that provided him with a solution: the biblical text, the fiction of Franz Kafka and the songs of children who survived the war by living in the forests.

17 For an insightful mapping of scholarship and literary criticism of Appelfeld's work since the 1960s, see (Schwartz 2011, pp. 383-85); (Schwartz 2014b). 
work, she claims that his fiction also fails to provide extensive detail and contextualization concerning the catastrophe in Europe; instead, it is highly lyrical, virtually poetic-a kind of prose poem. ${ }^{18}$ In this respect, Budick alludes to Alan Mintz (1984), who claimed that "everything having to do with what the French call the concentrationary universe [ ... ] is left out. Before, after, parallel to-yes; anything but the thing itself. Especially after, as if to say that a catastrophe can be known only through its survivors and its survivals" (Mintz 1984, pp. 206-7).

Referring to this "tendency to circle around-hint at, suggest, signal toward-the major sites of suffering and violence rather than represent them directly", Budick points to the musical aspect of Appelfeld's work: "Anyone who has heard Appelfeld read his own texts aloud will immediately understand what I mean concerning the musicality of this writing. It can be glimpsed as well as the text's proliferation of sound repetitions and irregular and imperfect rhymes" (Budick 2005, p. 148). Moreover, by calling attention to the way Jewish liturgy, such as the prayer "Shema Israel", is used in Appelfeld's literary texts, she connects between his poetic testimony of the Holocaust and his religious conception. In his essay "Beyond Despair", Appelfeld recalls:

Anyone who lived through the Holocaust will never forget the cries of "Hear O Israel" which shattered the air and shook the earth [ ... ] what happened during the Holocaust was not "hazara biteshuva" (a "return to religious observance") but rather contact with an atmosphere permeated by a kind of mythic depth, the stratum out of which [ ... ] faith arises [ ... ] Religious feelings during the Holocaust broke out on all sides, expressed silently, and in the sounds of song and prayer [ ... ] For the children it was perhaps more "primordial"—contact with the trees in the forest, the moist earth, the straw, sucking fluids from the roots of the trees, the night skies. These contacts with a hostile space, for us, homeless and orphaned, had qualities that were beyond "discovery" or curiosity [ ... ] I call these feelings religious, the fundamental religious sentiments [ ... ] (Appelfeld 1979, pp. 45-49)

Like Schoenberg, Appelfeld points to the encounter between a divine transcendence conveyed throughout this basic Jewish prayer, which refers to the First Commandment of the monotheistic God, and the horrific experience of the Holocaust. Whereas in 1948 Schoenberg speaks of "the confession of the Jew", who while facing death remembered who he was, Appelfeld speaks of "religious feelings" that arose during the disaster. Moreover, whereas Schoenberg merely alludes to them in his opera Moses und Aron, Appelfeld mentions the sounds of song and prayer explicitly.

Accordingly, I would claim that Appelfeld's "poetics of hints" discussed by scholars is generated in the way he shapes the semantic opposition between sounds and silence in his work. In what follows, I will show how sound images of muteness and stuttering, which are shaped in order to deal with the traumatic unsayable, are strongly connected to his conception of Jewish tradition. By combining the old with the new, traditional figures and innovative poetics, Appelfeld seeks new modes for expressing the catastrophe. Embedding theological tropes, such as the revelation associated with the biblical prophet or the sounds of Jewish liturgy, thus exemplifies not only the interweaving of music and literature, but also how the transcendent and the divine are revealed in the secular aesthetic realm as an essential method of working through the historical trauma.

The second context extensively explored by scholars is Appelfeld's attitude to the Jewish (and Christian) religion, namely to the sacred traditions and liturgy, including the concept "religiosity" that he insisted his literature should be identified with. ${ }^{19}$ Like Eliezer Schweid (1995), or Yigal Schwartz (2001) among others, Avidov Lipsker (2011)examines the metaphysical aspects of Appelfeld's literature as they are conveyed through prosodic principles. Discussing the musical opening of the

18 Sidra DeKoven Ezrahi, for her part, explores the journey trope and travel narrative at the heart of Appelfeld's writing about the Holocaust. This journey which has many facets (e.g., between Bukovina and Jerusalem), is not only thematic but is also manifested in the movement within language and the crossing of literary genres (DeKoven Ezrahi 2000, p. 180).

19 See, for instance, how Appelfeld $(1979$, p. 71) identifies this concept when referring to Yosef Haim Brenner's work. 
story "The Hunt", he claims that Appelfeld conveys the sounds of primordial ritual in the rhythms of iambs and anapests (Lipsker 2011, pp. 261-62). The musical aspect is also elucidated by other scholars, who identify incoherent, unstable language consisting of gaps and silences (Ratok 1989; Fischler 1997; Arbel 2005; Schwartz 2014a). Michal Goldvicht explores different sound images and diverse repertoires such as classical music, Jewish folk music and liturgical music in Appelfeld's work. Moreover, she suggests examining the image of the "inner melody" in light of Hassidic Jewish mystical thought and liturgy in terms of which the voiceless melody of the soul is the highest level of the Hassidic "nigun" (Goldvicht 2005, p. 152). ${ }^{20}$ I intend to focus on these moments in which the verbal, semantic language deceases and becomes a site of sacred revelation. ${ }^{21}$ In this respect as well Appelfeld's literature bears witness to that which, according to Bialik, "falls out of words".

The connection between the aesthetic realm and Appelfeld's religious position is examined by Iris Milner (2013). She defines the author's "ethics of art and religion [ ... ] a renunciation of permanence for the purpose of opening up toward the other and the world", by quoting the last paragraph of his autobiographical memoir A Table for Two:

When I say "religious" I mean seriousness and a sense of obligation to art. I believe art is about creation - and not about the ego, or making an impression, or exuding a sense of superiority toward others. But it is all about calling forth feelings that connect with other people. Art that doesn't extend love, devotion, identification-cannot be meaningful art [... ] when I say "a religious attitude" I mean the belief that inside every person, landscape and still-life there is hidden a noble beauty (quoted in Milner 2013, p. 109).

By illuminating the intertwining between the aesthetic and the religious domains, Appelfeld talks about an experience revealed through art, that is to say, a creation that also calls for and enables an encounter with the other. Yigal Schwartz (2001) discusses this ethical approach as one that connects the "individual lament", a modernist form of Romanticism, and the "tribal eternity". In examining the status of the Holocaust in Appelfeld's religious position as reflected in his literary work, Schwartz presents two points of view: "From the more understandable perspective, it is described as an experience of enormous loss [ ... ] From the other perspective [ ... ] the Holocaust is described as an experience of mighty revelation. Here, and only here, the domain of horror is created in the deep connection between the individual and the tribe" (Schwartz 2001, p. 141). Schwartz concludes that Appelfeld's works repeatedly express a classical historiographical position in terms of which "the entry into history of the Jewish people in the eighteenth and nineteenth centuries severed it from its roots, thus bringing catastrophes down upon it before the ultimate catastrophe" (Schwartz 2001, p. 142).

I will exemplify these connections and interrelations between the secular and the religious, and between the poetic innovations and the traditional characters or figures manifested in images of sounds and silence, as these are demonstrated, among others, in Appelfeld's A Journey into Winter or Suddenly, Love. My claim, similar to Schoenberg's modernist music, is that in the face of the catastrophe, Appelfeld's modernist fiction does not forget the religious sources of Jewish tradition, but rather recalls them by repeatedly pursuing the sacred within the aesthetic domain of Jewish secular culture. While Schoenberg's opera questions the limits of classical musical conventions by developing means such as Sprechgesang, musical prose and 12-tone composition, Appelfeld's prose crosses the borders of traditional prose by emphasizing the non-semantic musical aspects of language. In both cases the

20 In this respect, Goldvicht refers to Moshe Halamish (1982), who discusses the meaning of silence in Hasidism and Kabbala. Compare also with (Ben Zaken 2005). Appelfeld admits to his fascination with Hassidism in general and the texts of Nachman of Breslov in particular, in an interview with Bendel and Horovitz (2018).

21 Schwartz (2014b, p. 525 note 18), who in an earlier essay explored the muteness as a "vehicle" for the religious realm in Appelfeld's prose, mentions in this context various scholars such as Dana Ben Zaken, Masha Itzhaki and Michal Goldvicht. I wish to elaborate on this point by claiming that not muteness alone, namely the absence of sound, but rather the suspension or destruction of the language's semantic meaning (until language becomes "pure" music) is Appelfeld's way of reverberating with the transcendence. 
stuttering associated with the biblical character of the tongue-tied prophet is manifested not only at the level of the plot, but also at the structural level of the musical or literary work.

\section{Against Telling: Stuttering as Revelation in A Journey into Winter and Beyond}

Appelfeld's poetics of hints, which surrounds but never directly confronts the Holocaust, is already demonstrated in his first story collection Ashes (1962). This poetics has become characteristic of the author's concern regarding the ethical modes of response and bearing witness to the catastrophe. His resistance to "great messages", repeated explanations and surplus interpretations was inspired by the sparingness and brevity of the biblical poetics as he admits to in "Beyond Despair":

The Hebrew language taught me how to think, to be sparing with words, not to intervene too much, and not to interpret [ ... ] if it weren't for Hebrew, I doubt whether I would have found my way to Judaism. Hebrew offered me the heart of Jewish myth, its way of thinking and its beliefs, from the days of the Bible to Agnon (quoted in Budick 2005, p. 143).

In an interview with Michael Gluzman (2000), Appelfeld talks of modern Hebrew literature as being highly verbal; a literature that prefers the "telling" mode of narration to that of the "showing". For Appelfeld, this preference demonstrates a non-aesthetic principle. Whereas he associates the "telling" with the long-winded, redundant debate of the Midrash, the "showing" is demonstrated for him in the biblical text. In his own literary work, he looks for an appropriate, "non-deceptive" mode of representation. The literary characters he shapes, partly his poetic doubles, manifest speech disabilities that hinder a classical, coherent telling.

Moreover, instead of "telling", that is, describing the events while interpreting and judging the story he tells his readers, Appelfeld renounces the stable meaning of language. As opposed to explanatory semantics, he rather frees the words of their semantic load by incorporating sound images that lack coherent meanings. This "non-sense" is conveyed through successions of sounds that are associated with forms of stuttering, mumbling and even muteness on the spectrum of that which cannot be directly understood. However, it is precisely from these musical moments in which speech flaws and gaps in the discourse interfere with verbal meanings, that his poetic testimony of the disaster emerges. This is also where theological figures come into play, and where Appelfeld transforms sacred concepts of revelation and prophecy into the poetic domain of his literature. In this respect, the unsayable, which reveals where the verbal semantic declines, is transcendental. The unsayable echoes exactly where Appelfeld stretches the limits towards the outside of verbal language. The divine is revealed through innovative poetics that transgresses its own lines.

The story "Cold Spring" of Ashes describes a group of survivors who find shelter during the war. When they finally leave the shelter, they discover that all their relatives have been murdered. This discovery is conveyed through their meeting with a man they were sent to in order to learn "who is still alive and worth searching for and who has been killed" (Appelfeld 1997, p. 209). The narrator admits to his impediment: "had not regained the power of speech. I tried to say something but could not. I felt that if only I could speak I would be able to suggest a solution" (Ibid.). This flaw is reminiscent of Moses, the tongue-tied prophet, who is alluded to in the following scene. Like in the encounter with the rabbi, a magician (Ish mofet) from the novel A Journey into Winter, Appelfeld alludes to the biblical story: "Quite, quite, a man greeted us at the door. Take your shoes off, take your shoes off. It's forbidden to wear shoes in a holy place" (Appelfeld 1997, p. 211). Here, the allusion invokes the revelation of God through the Burning Bush as related in Exodus: "And he said, Draw not nigh hither: put off thy shoes from off thy feet, for the place whereon thou standest is holy ground" (Exodus 3, 5).

During a ritual of sanctification, the Jewish survivors are told to say words, which the narrator, retrospectively cannot remember saying; only that they had to "repeat the words loudly and the room was full of trembling and sound [ ... ] one by one they ascended the stage, shrouded in blue, and we recognized them by their rustling and the way they lifted their necks" (Appelfeld 1997, p. 211). What is revealed through the sounds of words whose meaning can no longer be transmitted, is a terrible 
recognition of loss and death: "Zeitel broke away from us, shouting, we are orphaned, children, we are orphaned" (Ibid.). This brevity of words characterizes Appelfeld's poetic sites of revelation.

Orphanhood recurs in A Journey into Winter (2000), where the protagonist and narrator, Kuti, whose parents died when he was a child, departs at the age of 13 from his adopted mother. Again, here, the narrator, who intends to become a writer, suffers from a verbal impediment. For instance, he feels how his stuttering is not limited to speech only, rather his writing stutters as well (Appelfeld 2000, p. 91). Despite his serious speech handicap, Kuti manages to work at a resort hotel that caters for those who have come to seek the wisdom of the same 'ish mofet', whose advice Kuti himself has sought concerning his stammer. ${ }^{22}$ The cure given to Kuti consists of the Hebrew letters of the Jewish prayers, which the young boy is told to write every morning, afternoon and evening. The act of Hebrew writing becomes a ritual that reverberates with the sacred words of God: "Endeavor to write in clear letters and check that you haven't left any letters out. Thus will your prayers be entered with those of the Jewish people" (quoted in Budick 2005, p. 144). Later, the rabbi explicitly identifies Kuti with the figure of the biblical prophet, calling him Moses and mentioning the Ten Commandments.

As the war approaches, he and the other workers and guests at the hotel band together to mount an armed resistance against the Ukrainian and German armies, at which point he begins to lose his speech impediment. The stuttering, however, is engraved in the poetic language itself as demonstrated by Rachel Albeck-Gidron (2011, pp. 159-61). Focusing on the mythical structure of A Journey into Winter she reads Kuti's speech impediment not only thematically, but also at the structural level of the text. In this reading, the disability illuminates Appelfeld's refusal to accept the terrible mechanism at the core of every verbal significance system, which replaces the full "real signified" with its reductive signifier. The refusal to speak is therefore a refusal to accept the linguistic rule and find satisfaction in the verbal sign. The stuttering narrator tells the story of the resort people who flee from the mountain as the soldiers are closing in. Precisely because they have nothing to lose, this narration maintains its flaws, refusing to give way to the loss entailed in verbal language.

Explicit exploration of the narrating mode and testimonial language can be found in the novel Suddenly, Love (2003), as demonstrated by Ernst, the narrator who identifies with Adorno:

There were years when he didn't talk about it at all. He was convinced that writing about the Holocaust was impossible, forbidden. He found firm supporters for this opinion. The philosopher Theodor Adorno, for example, claimed that writing poetry after Auschwitz was "barbaric". Ernst accepted this without challenge (Appelfeld 2014, p. 114).

Ernst, a 70-year-old Red Army veteran from Ukraine arrives, almost by accident, in Israel after World War II. A retired investment adviser, he lives alone and spends his time laboring over his unpublished novels. Irena, in her mid-thirties, is the unmarried daughter of Holocaust survivors who has been taking care of Ernst since his surgery two years earlier. Haunted by the past, Ernst fails to pursue his writing, and seems to have lost the will to live. When Irena moves into his home, encouraging him in his work and easing his pain, Ernst regains his sense of self and discovers the path through which his writing can flow. To his amazement, he also discovers love. At some point, Irena tells him of a dream she had in which he and his grandfather were praying. Ernst's response exposes that which can no longer be repaired. His father, who lost the ability to pray, passed on his muteness to his son. This silence embedded in the son is transformed in the aesthetic realm of the son's poetic writing. There, and only there, does the son seem to encounter his grandfather's lost prayer. The Jewish prayer thus becomes a poetics of memory, which bears witness not only to the lost sacred tradition but also to the other loss associated with the catastrophe of World War II.

Similar to Ervin, the protagonist of Appelfeld's literary autobiography The Man who Never Stopped Sleeping (2010) or the protagonist of his poetic memoir A Story of Life, Ernst struggles to write, while

22 Reading this novel in the light of the issue of verbal disability is found in (Itzhaki 2005) and (Ben-Mordechai 2014). Compare also with (Budick 2005, pp. 144-46). 
confronting the demons of the past. Eventually, he finds his way into writing by reviving the culture of his grandfather (Jewish religiosity):

At night Irena dreams that they are walking together in the Carpathian Mountains [ ... ] "when did I become so closely acquainted with this place? After all, I was never there." She is amazed. Ernst smiles and says, "we were born here. Because of some mistake we are driven from this paradise and cast into exile. But finally the mistake has been corrected and we have returned to the place where God and man dwell together. And soon we will come to the sanctuary". "The sanctuary"? Irena asks in surprise. You have nothing to fear. Grandfather's house is his sanctuary. There is no altar; no one makes sacrifices. It's just the gateway to heaven" (Appelfeld 2014, pp. 223-24).

As we saw in his essays, Appelfeld formulates what is initially conceived as an impossible connection: the horror of the Holocaust perceived as a deep religious experience. Aware of this paradox, Appelfeld speaks about the void in which old-new words were emerging in order to express that which was inexpressible. He connects the traumatic experience with Jewish tradition by distinguishing between the cultural aspect of Judaism (religiosity) and its religious laws and rituals (Halacha). In this respect, Appelfeld embodies the Romantic wish to reunite with the ancient fathers, the recall of the ancient tribe.

After Jewish prayer was no longer possible, a consequence of processes of modern secularism, including Zionism, the Jewish national movement ("return into history")—what remains is a deep mode of observing. This mode belongs to the realm of the sacred. This is also the case with words of mystic connotation, such as wonder, reveal, angel, prayer, magic, sanctuary-which Appelfeld repeatedly incorporates in his literature in his search for poetic means to bear witness to the disaster. Like awakening from deep oblivion, the recall of Jewish tradition and religiosity is by no means going back. Rather, this is a process of integrating the old with the new, the religious with the secular as the sacred is conveyed through the aesthetic realm of a modern Jewish culture and Hebrew literature:

It's hard for Irena to understand whether Ernst is talking about his life or about his writing. His writing preoccupies him no less than his life. Over the past few days she heard him murmur: Facts, facts, and not descriptions. An overabundance of details only blurs the point. The prose of the Bible has to be a model for any writer (Appelfeld 2014, p. 117).

Appelfeld's preoccupation with biblical language finds its way to his literary protagonist. Like Schoenberg, who found in musical prose the principle of a true expression, Appelfeld formulates the idea of "good writing" through Ernst. Drawing inspiration from the Bible, the divine creation and the laws of the monotheistic God, such as the Ten Commandments, this is not only a question of plot, but also of structure. The rejection of the ornamental by Schoenberg, as mentioned by Adorno, seems to be reflected here in the refusal of the "decoration", as the textile texture conveys the structure of a true poetic text:

It is now of the greatest importance to Ernst for his writing to be clear, orderly, without superfluity, and without any exaggerations. If a sentence has an air of coquetry or a hint of ornamentation, he crosses it out [ ... ] Writing has to be direct and to the point, without twists [ ... ] Good writing has to be like Grandfather's peasant smock: a simple tunic, with no decoration, comfortable to wear. Once Grandfather told him that there is not a superfluous word in the Bible. Every word counts and has its place (Appelfeld 2014, p. 222).

To conclude, by using religious allusions and theological concepts, Appelfeld's testimony of the catastrophe is shaped within the aesthetic realm of modern Hebrew literature. This is not an explanatory or interpreting writing that tells of the disaster, but rather an attempt to find an alternative mode of representation. This is reflected in the model of stuttering, revealed to him in the character of the biblical prophet. By transforming the thematic principle into a structural one, Appelfeld stretches the lines of the literary text towards its non-semantic musicality, where eventually, silence also plays a role: 
I do not believe in great messages [ ... ] I know that in our days a lot of writers became politicians. But imagine Bach a politician. With Bach, you should sit and listen to him [ ... ] The melody comes into you. You feel Bach in your hands and legs. You become full of Bach. This is not a message. If I give you a book—read it, be close to it, connect to the people that are in this book. This is what I am doing. And I have done this for fifty-five years. And I'm still at the beginning (quoted in Gold 2013, p. 444).

\section{Conclusions: The Unsayable of Jewish Secular Culture}

Arnold Schoenberg and Aharon Appelfeld deal with issues of tradition and innovation as an inherent part of their cultural-musical and literary-creation. For both, the return to Jewish religion as such is impossible; they insist, however, on recalling sacred traditions within new aesthetic realms. Schoenberg composes innovative music to the Lutheran German translation of the Bible. The biblical tongue-tied prophet is placed at the center of his avant-garde opera, thus demonstrating the encounter between different movements: the mechanism of cultural memory and oblivion, the conversion to Protestantism and the return to Judaism, and musical traditions in contrast to innovative styles and techniques. For the plot, Schoenberg explores the question of the non-representable monotheistic God, and in so doing, creates a connection between a theological conception of the monotheistic religion and the musical system.

As the article shows, Schoenberg creates the sacred sphere (revelation, prophecy) by the subversion of classical conventions of melody and harmony. Therefore, the stuttering language of Moses is conveyed through the Sprechgesang, the musical prose and the dodecaphonic system, which testify to the non-representability of the Jewish God. This inability to express the imageless God, which culminates in the prophet's defeat, Schoenberg later associates with the question of bearing witness to the Holocaust. Like Schoenberg, Appelfeld also works through traumatic experience by exploring aesthetic means to testify to human loss and historical disaster. This language has to be free of ornaments and repetitions, similar to the Hebrew letters Kuti writes in his notebook, or the peasant shirt of Ernst's grandfather, and similar to the brevity of Schoenberg's musical prose. In this respect, not only Kuti, but also other stutterers in Appelfeld's novels and stories, who become narrators and true writers, and whose speech disability is transformed into their own authorship, bear witness to immense loss and horrific experience.

In conclusion, this essay demonstrates how Schoenberg and Appelfeld explore ways to transform the trace of that which was lost into the aesthetic realm of a secular creation. In their works, which belong to a modern non-religious repertoire, this loss reverberates with sacred Jewish traditions. Both the composer and the author look for alternative means of representation that subvert and deviate from traditional (verbal and aesthetic) sign systems that betrayed human values, or failed to bear true witness to disastrous reality. When the verbal language of the literary work extends itself through the music of the words, or when the musical style of the Bel Canto is challenged by the Sprechgesang, these two sign systems "begin to stutter, to murmur, or to mumble; then the entire language reaches the limit that sketches the outside and confronts silence" (Deleuze 2000, p. 28); thereby "always returning upon the paths of time, we are neither ahead nor behind: late is early, near far" (Blanchot 1992, p. 58).

Moreover, while seeking to recall what has died and got lost within what has not yet begun, Schoenberg's and Appelfeld's work bears witness to that which, according to Bialik, rises out of the void (Bialik 2000, p. 26). From this perspective the unsayable of the traumatic experience in the face of a historical disaster recurs throughout the challenge and transgression of aesthetic conventions. In other words, the transcendent sphere encapsulated in sacred, theological concepts (prophecy, revelation) returns within the musical and poetic avant-garde (musical prose, 12-tone composition, prose poem, non-semantic or semiotic fiction) as a sound-that of old traditions that can only be heard through the voices of a new Jewish culture.

Funding: This research received no external funding.

Conflicts of Interest: The author declares no conflict of interest. 


\section{References}

Adorno, Theodor W. 2002. Sacred Fragment: Schoenberg's Moses und Aron. In Quasi una Fantasia. Translated by Rodney Livingstone. London and New York: Verso, pp. 225-48.

Adorno, Theodor W. 2004. Philosophy of New Music. Translated by Anne G. Mitchell, and Wesley V. Blomster. New York and London: Continuum.

Albeck-Gidron, Rachel. 2011. The Lexicon and The Flood: Appelfeld and the Discourse of Survivors from the First Ark. In Twenty-Four Readings in Aharon Appelfeld's Literary Work. Edited by Avi Sagi and Avidov Lipsker. Ramat Gan: Bar Ilan University Press, pp. 153-62.

Appelfeld, Aharon. 1979. Essays in the First Person. Jerusalem: Hasifriya Hatzionit. (In Hebrew)

Appelfeld, Aharon. 1997. Cold spring. In The Oxford Book of Hebrew Short Stories. Edited by Glenda Abramson. Translated by Jacob Sloan. Oxford and New York: Oxford University Press, pp. 204-12.

Appelfeld, Aharon. 2000. A Journey into Winter. Jerusalem: Keter. (In Hebrew)

Appelfeld, Aharon. 2004. A Story of a Life. Translated by Aloma Halter. New York: Schocken Books.

Appelfeld, Aharon. 2014. Suddenly, Love. Translated by Jeffrey M. Green. New York: Schocken Books.

Arbel, Michal. 2005. Between Speech and non-Speech, Author and Reader in 'Cold Spring' and 'Kiti'. Mikan 5: 119-32. (In Hebrew)

Assmann, Jan. 2006. The Advance in Intellectuality: Freud's Construction of Judaism. In New Perspectives on Freud's "Moses und Monotheism". Edited by Ruth Ginsburg and Ilana Pardes. Niemeyer: Tübingen, pp. 7-18.

Auner, Joseph. 2007. Schoenberg as Moses and Aron. The Opera Quarterly 23: 373-84. [CrossRef]

Barzel, Hillel. 1981. Essays on Modern Hebrew Novelists. Israel: Yachdav. (In Hebrew)

Ben Zaken, Dana. 2005. Space, Muteness and Speech in Appelfeld's Stories. Mikan 5: 111-17. (In Hebrew)

Bendel, Neta'el, and Ariel Horovitz. 2018. An Interview with Aharon Appelfeld. Makor Rishon. Available online: https://www.makorrishon.co.il/judaism/10939/ (accessed on 3 May 2019).

Ben-Horin, Michal. 2018. Choice of Language and the Quest for Israeli Identity in the Works of Tuvia Ruebner and Aharon Appelfeld. Polish Political Science Yearbook 47: 414-23. [CrossRef]

Ben-Mordechai, Yitzhak. 2014. Disability as Metaphor in Two Novellas of Aharon Appelfeld. Yod - Revue des études hébraïques et juives 19. [CrossRef]

Berry, Mark. 2008. 'Arnold Schoenberg's “'Biblical Way': From 'Die Jakobsleiter' to 'Moses und Aron'”. Music and Letters 89: 84-108. [CrossRef]

Bialik, Haim Nahman. 2000. Revealment and Concealment in Language. In Revealment and Concealment in Language. Translated by Jacob Sloan. Jerusalem: Ibis Editions, pp. 11-26.

Blanchot, Maurice. 1992. The Writing of the Disaster. Translated by Ann Smock. Lincoln and London: University of Nebraska Press.

Budick, Emily Miller. 2005. Aharon Appelfeld's Fiction: Acknowledging the Holocaust. Bloomington and Indianapolis: Indiana University Press.

Caduff, Corina. 1999. Der Gottverlorene Ton: Musik in Texten von Kleist, Kafka und Anne Duden. In Gott und Göze in der Literature der Moderne. Edited by R. Sorg and B. Würffel. Munick: Fink, pp. 245-57.

Covach, John. 1996. The Sources of Schoenberg's 'Aesthetic Theology'. 19-Century Music 19: 252-62. [CrossRef]

Dahlhaus, Carl. 1978. Die Idee der absoluten Musik. Kassel: Bärenreiter.

Daunser, Hermann. 1997. Musikalische Prosa. In Die MGG. Musik in Geschichte und Gegenwahrt. Edited by Ludwig Finscher. Kassel: Bärenreiter, vol. 6, pp. 857-66.

DeKoven Ezrahi, Sidra. 2000. Booking Passage Exile and Homecoming in the Modern Jewish Imagination. Berkley: University of California Press.

Deleuze, Gilles. 2000. He Stutters. In Gilles Deleuze and the Theater of Philosophy. Edited by Constantin V. Boundas and Dorothea Olkovski. Translated by Constantin V. Boundas. London and New York: Routledge, pp. 23-29.

Derrida, Jacques. 1998. Archive Fever: A Freudian Impression. Translated by Eric Prenowitz. Chicago: The University of Chicago Press.

Fischler, Bracha. 1997. To Silence the Voice of Language. In Between Cold and Smoke. Edited by Yitzhak Ben Mordehai and Iris Parush. Beer Sheva: Ben Gurion, pp. 213-36. (In Hebrew)

Floros, Constantin. 2011. 'Die Musik soll nicht schmücken, sie soll wahr sein': Zur Ästhetik der zweiten Wiener Schule. In Musik-Kontexte. Festschrift für Hanns-Werner Heister. Edited by Thomas Phleps und Wieland Reich. Münster: Monsenstein und Vannerdat, vol. 1, pp. 258-64. 
Freud, Sigmund. 1967. Moses and Monotheism. Translated by Katherine Jones. New York: Vintage Books.

Gluzman, Michael. 2000. An Interview with Aharon Appelfeld. Mikan 1: 150-65. (In Hebrew)

Gold, Nili. 2013. Aharon Appelfeld in Conversation with Nili Gold. The Jewish Quarterly Review 103: 434-45. [CrossRef]

Goldstein, Bluma. 1992. Re-inscribing Moses. Heine, Kafka, Freud, and Schoenberg in a European Wilderness. Cambridge: Harvard University Press.

Goldvicht, Michal. 2005. The Music in Aharon Appelfeld's Work. Mikan 5: 141-53. (In Hebrew)

Gyger, Elliott. 2007. Speech, Song and Silence: Modes of Utterance in Moses und Aron. The Opera Quarterly 23: 418-40. [CrossRef]

HaCohen, Ruth. 2006. Psychoanalysis and the Music of Charisma in the Moses of Freud and Schönberg. In New Perspectives on Freud's "Moses und Monotheism". Edited by Ruth Ginsburg and Ilana Pardes. Niemeyer: Tübingen, pp. 177-96.

Halamish, Moshe. 1982. On Silence in Kabbalah and Hasidism. In Religion and Language: Essays in General and Jewish Philosophy. Edited by Moshe Halamish and Asa Kasher. Tel Aviv: Touro University Press, pp. 79-90.

Hanssen, Beatrice. 2006. Dissonance and Aesthetic Totality: Adorno Reads Schoenberg. In Sound Figures of Modernity: German Music and Philosophy. Edited by Jost Hermand and Gerhard Richter. Madison: The University of Wisconsin Press, pp. 181-200.

Itzhaki, Masha. 2005. But I am Slow of Speech, and of a Slow Tongue: Reading 'Journey into Winter'. Mikan 5: 133-40. (In Hebrew)

Latham, Edward D. 2000. The Prophet and the Pitchman: Dramatic Structure and its Musical Elucidation in Moses und Aron, Act 1, Scene 2. In Political and Religious Ideas in the Works of Arnold Schoenberg. Edited by Charlotte M. Cross and Russel A. Berman. New York: Taylor \& Francis, pp. 131-58.

Lipsker, Avidov. 2011. From Myth to History: Reading 'The Hunt' and Katerina. In Twenty-four Readings in Aharon Appelfeld's Literary Work. Edited by Avi Sagi and Avidov Lipsker. Ramat Gan: Bar Ilan University Press, pp. 261-84.

Locke, Arthur Ware, and E. T. A. Hoffmann. 1917. Beethoven's Instrumental Music: Translated from E. T. A. Hoffmann "Kreisleriana" with an Introductory Note. The Musical Quarterly 3: 123-33. [CrossRef]

Mäckelmann, Michael. 1984. Arnold Schönberg und das Judentum. Hamburg: Verlag der Musikalienhandlung Karl Dieter Wagner.

Martinec, Thomas. 2018. Musik. In Franz Kafka in Context. Edited by Carolin Duttlinger. Cambridge: Cambridge University Press, pp. 128-36.

Milner, Iris. 2013. Life in the Cafe: On Diasporism in Aharon Appelfeld's 'All Whom I Have Loved' and 'A Table for One'. The Jewish Quarterly Review 103: 459-68. [CrossRef]

Mintz, Alan. 1984. Hurban: Responses to Catastrophe in Hebrew Literature. New York: Columbia University Press.

Miron, Dan. 1979. Open Notebook. Tel Aviv: Sifriyat Poalim. (In Hebrew)

Pinsker, Shachar. 2014. The Language that was Lost on the Road: Discovering Hebrew through Yiddish in Aharon Appelfeld's Fiction. Journal of Jewish Identities 7: 129-41. [CrossRef]

Ratok, Lili. 1989. House on the Edge of the Abyss. Tel Aviv: Heker. (In Hebrew)

Ringer, Alexander L. 1990. Arnold Schoenberg. The Composer as Jew. Oxford: Clarendon Press.

Schoenberg, Arnold. 1958. Briefe. Edited by Erwin Stein. Mainz: B. Schott's Söhne.

Schoenberg, Arnold. 1975. Style and Idea: Selected Writings of Arnold Schoenberg. Edited by Leonard Stein. Berkeley and Los Angeles: University of California Press.

Schoenberg, Arnold. 1984. Moses und Aron. Opera. Edited by Christian Martin Schmidt. London: Ernst Eulenburg Ltd.

Schoenberg, Arnold. 1988. Arnold Schoenberg Self-Portrait: A Collection of Articles, Program Notes and Letters by the Composer about his Own Works. Edited by Nuria Schoenberg Nono. Pacific Palisades: Belmont Music Publishers.

Schwartz, Yigal. 2001. Aharon Appelfeld: From Individual Lament to Tribal Eternity. London and Hannover: Brandies University Press.

Schwartz, Yigal. 2011. A Preacher without a Pulpit, A Believer Without a Church: in the Footsteps of the Novel. In Wild Blossoming. Twenty-four Readings in Aharon Appelfeld's Literary Work. Edited by Avi Sagi and Avidov Lipsker. Ramat Gan: Bar Ilan University Press, pp. 383-404. (In Hebrew)

Schwartz, Yigal. 2014a. Le'at (Slowly): The Orchestration of a Motif in Appelfeld's Fiction. Yod - Revue des études hébraïques et juives 19. [CrossRef]

Schwartz, Yigal. 2014b. The Narrative Art of Aharon Appelfeld. Yehuda: Kineret, Zmora-Bitan, Dvir. (In Hebrew) 
Schweid, Eliezer. 1995. Religious Morality in the Stories of Aharon Appeldeld. Moznayim 69: 3-6. (In Hebrew) Shaked, Gershon. 1985. The New Wave in Hebrew Fiction. Jerusalem: Keter. (In Hebrew)

Slavet, Eliza. 2008. Immaterial Materiality: The 'Special Case' of Freud's Theory of Jewishness. Jewish Studies Quarterly 15: 353-82. [CrossRef]

Sokoloff, Naomi. 2005. Aharon Appelfeld and the Translingual Imagination. Mikan 5: 91-100. (In Hebrew)

Steck, Odil Hannes. 1981. Moses und Aron: Die Oper Arnold Schoenbergs und ihr biblischer Stoff. München: Kaiser.

Steiner, George. 1967. Language and Silence: Essays on Language, Literature and the Inhuman. New York: Atheneum. White, Pamela C. 1985. Schoenberg and the God-Idea: The Opera Moses und Aron. Michigan: UMI Research Press.

Yerushalmi, Yosef Hayim. 1991. Freud's Moses: Judaism Terminable and Interminable. New Haven and London: Yale University Press.

C 2019 by the author. Licensee MDPI, Basel, Switzerland. This article is an open access article distributed under the terms and conditions of the Creative Commons Attribution (CC BY) license (http://creativecommons.org/licenses/by/4.0/). 